\title{
Mitigating Cyber Sexual Harassment: An Insight from India
}

\author{
Deepa Sethi ${ }^{*}{ }^{*}--$ Sanchita Ghatak ${ }^{2}$ \\ ${ }^{*}$ Associate Professor, Indian Institute of Management, Kozhikode, India \\ Email:deepa@iimk.ac.in \\ ${ }^{2}$ Assistant Professor, Jaipuria Institute of Management, Lucknow, India \\ Email: sanchita.ghatak@jaipuria.ac.in
}

\begin{abstract}
Cyber Sexual Harassment (CSH) can be defined as the use of the internet to make uninvited advances, communications or interactions with another person or entity. This can be in various forms like unsolicited posts and comments on social media sites, emails, texts, graphic images and posts directed at the victim, instant messaging etc. This study mainly focuses on finding out the awareness about gender based cyber sexual harassment so that the perception of women on cyber-crime with reference to Indian psyche and their awareness level can be understood. It tries to find gaps between the perception and reality of these incidents and finally develop a preliminary self-help model to follow before pursuing legal action. The findings of the research will draw a path for women to understand that they should not ignore the harasser if they fall a prey to CSH and be sensitized with the action to be taken in such cases.
\end{abstract}

Keywords: Cyber sexual harassment, Internet, Victim.

Licensed: This work is licensed under a Creative Commons Attribution 4.o License.

\section{Introduction}

Staying connected with geographically distant friends and relatives had never been so easy. The advent of internet as a technology to enable easy and quick communication, has brought in big snags along with it. While we are happy to find our lost friend after 2-3 decades, communication with some new ones, we sometimes fall prey to some strangers who by their obnoxious online behavior tend to seize our mental peace, self-esteem and even leave us wondering if the incident that happened was really worth it. It gets us to a feeling of embarrassment and humiliation.

This has become a very common problem all the more with coming up of web 2.0 technology which basically promotes synchronous communication and interactivity. Web 2.0 platform has given rise to very important advances in communication these days, the social media sites and apps like Facebook, twitter, WhatsApp etc. which if used in a constructive way improve efficiency and effectiveness but have a deleterious side too. These promotes sexual harassment on the internet which is predominantly called Cyber Sexual Harassment (hereinafter to be mentioned as CSH).

$\mathrm{CSH}$ can be defined as the use of the internet to make uninvited advances, communications or interactions with another person or entity. This can be in various forms like unsolicited posts and comments on social media sites, emails, texts, graphic images and posts directed at the victim, instant messaging etc.

This has been identified to be of the following types:-

1. Gender Harassment: it can be of verbal and graphic types. It is described unsolicited verbal and visual comments and remarks that abuse individuals because of their gender or is a stimuli to invoke negative sentiments. 
2. Unwanted Sexual Attention: it happens when the harasser uses personal communication for conveying sexually inclined messages like:

- victim's sex organs

- victim's sex life

- intimate subjects

- $\quad$ sex-related images or sounds

- $\quad$ hint upon or offer sex-related activities.

Further, a harasser who uses unwanted sexual attention to harass a victim online, intends to solicit sexual support from his/her victim either on the internet or in person.

3. Sexual Coercion: This is a very common form of sexual harassment on internet. In this, the victim is forced or pressurized to provide sexual cooperation. This is done by various means like putting threats on family members, of victim's social status etc.

\section{Literature Review}

Some different form of sexual harassment on net are Virtual Rape via Cyberspace, Cyber Morphing, Cyber Pornography, Cyber Defamation (HalDer and JaishanKar, 2009; Calvete, Orue,Estévez, Villardón and Padilla, 2010; Agarwal 2013; Beckman, Hagquist, and Hellström, 2013; Bastiaensens et al., 2014; Citron, 2014; Fenaughty and Harré, 2013).It has been found that violence against women specifically sexual abuse on women are becoming grave day by day. Internet adds up to this form of crime against women. United nation describes sexual harassment as "any act of gender-based violence that results in, or is likely to result in, physical, sexual or mental harm or suffering to women, including threats of such acts, coercion or arbitrary deprivation of liberty, whether occurring in public or in private life (Empowering women against cyberviolence 2011).

Further to this, Majumdar (2003) suggested that violence against women is neither cultural nor region specific, rather it spreads across all class and community. It has also been observed that women as compared to men face more of online sexual harassment simply because of gender issue (Nussbaum, 2010; Citron, 2014; Cross, 2014). According to Halder et al (2010), it has been observed that many such crimes are the result of women sharing their personal details, passwords etc. sometimes due to less awareness of such crimes or due to pressure from family (spouse) or friends(specially boyfriends or ex-mates). Such cases are increasing all the more because people are aware that there is no clear law against such crime as compared to law against rape or physical violence (Walia 2013). In a very interesting study by Meyer and Cukier (2006) with some fake male and fake female ids of Facebook, it was found that female ids get more sexually explicit and offensive comments as compared to male, which shows that it's because of the gender issues that such crimes are getting patronage. So gender becomes an important aspect to consider while studying cyber sexual harassment (Chen, Zhou, Zhu, and Xu, 2012; Yang, Kiang, Chen, and Li, 2012; Dadvar and de Jong, 2012; Dinakar, Reichart, and Lieberman, 2011; Dinakar, Jones, Havasi, Lieberman, and Picard, 2012; Ptaszynski et al., 2010; Reynolds, Kontostathis, and Edwards,2011; Dadvar,Jong de, Ordelman, and Trieschnigg, 2012) because in any case maximum victimization has been on women only.

Some studies have recently reported that these are some common crimes women face on internet specifically on social media sites flaming(displaying hostility by insulting, swearing or using otherwise offensive language) on YouTube (Moor, Heuvelman, and Verleur,2010), less accountability by means of anonymity ((Lapidot-Lefler and Barak, 2012; Rowe, 2014; Santana, 2014), discourteous comments (Hmielowski, Hutchens, and Cicchirillo, 2014).

Apart from these mentioned above some major researches on technology based sexual harassment are listed in Table 1.

Thus it becomes all the more important for the women to know what are the do's and don'ts while interacting on internet, which will help them to protect themselves from such incidents. Not much research has been done on the field of CSH more specifically in the Indian context. In fact, there is a dearth of literature on measurement of magnitude of harassment and also type of harassment and the initial strategy of tackling the issues.

This study mainly focuses on finding out the awareness about gender based cyber sexual harassment so that the perception of women on cyber-crime with reference to Indian psyche and their awareness level can be understood. It tries to find gaps between the perception and reality of these incidents and finally develop an action plan to follow before pursuing legal action. The findings of the research will draw a path for women to understand that they should not ignore the harasser if they fall a prey to CSH and be sensitized with the action to be taken in such cases. 
Table-1. Related studies.

\begin{tabular}{|c|c|}
\hline $\begin{array}{l}\text { Technology-Facilitated } \quad \text { Sexual } \\
\text { Violence Victimization } \\
\text { Dimensions }\end{array}$ & Studies Identified \\
\hline Online sexual harassment & $\begin{array}{l}\text { Ballard and Welch ;Baumgartner, Valkenburg, and Peter (2010), } \\
\text { Burke, Wallen, Vail-Smith, and Knox (2011), DreBing, Bailer, Anders, } \\
\text { Wagner, and Gallas (2014), and Staude-Mu“ller, Hansen, and Voss } \\
(2012)\end{array}$ \\
\hline $\begin{array}{lll}\text { Gender- } & \text { and } & \text { sexuality-based } \\
\text { harassment }\end{array}$ & Ballard and Welch \\
\hline Cyber-obsessive pursuit & $\begin{array}{l}\text { Ballard and Welch, Burke et al. (2011), Dreßing et al. (2014), and } \\
\text { Thompson and Morrison (2013) }\end{array}$ \\
\hline Image-based sexual exploitation & $\begin{array}{l}\text { Burke et al. (2011), Dreßing et al. (2014), Drouin and Tobin (2014), } \\
\text { Drouin, Ross, and Tobin (2015), Ga'mez-Guadix, Almendros, Borrajo, } \\
\text { and Calvete (2015), and Thompson and Morrison (2013) }\end{array}$ \\
\hline $\begin{array}{l}\text { The use of a carriage service to } \\
\text { perpetrate a sexual assault or coerce } \\
\text { an unwanted sexual experience }\end{array}$ & $\begin{array}{l}\text { Baumgartner, Valkenburg, and Peter (2010), Ga'mez-Guadix et al. } \\
\text { (2015), and Thompson and Morrison (2013) }\end{array}$ \\
\hline
\end{tabular}

\section{Research Methodology}

Qualitative methods are useful to investigate little known facts and cognize peoples' complex existence (Morrow, 2007). With this view, we employed an inductive and exploratory qualitative approach, grounded in the experiences of women, to obtain initial insights as to how women can proceed when handling cyber sexual harassment. Researchers using quantitative value studies, that apply random and statistically representative sampling so that results can be generalized to populations. However, researchers doing qualitative analysis value the complexity of meaning provided by smaller, information-rich samples (Morrow, 2007; Sandelowski, 1995). Consequently, qualitative research is carried out with smaller sample sizes and relies on purposeful sampling methods. The number of a qualitative sample size is less important than the quality of the data gathered in connection with the aim of the research. Thus, the sample size of the present work was fitting because of the exploratory nature of the study, the limited focus of the study, the information rich nature of the sampled individuals, the in-depth nature of the interviews, and the triangulation of the data sources and analytic approaches (Sandelowski, 1995). Therefore, data collection concluded when it reached a level of saturation and started creating redundancy (Corbin and Strauss, 2014).

Thirty-two persons were identified for the study based on purposeful sampling. Each participant was asked if he/she was aware of cyber sexual harassment. Twenty persons agreed and hence they were chosen for further probing. Among the participants, ten were professionals from the age group 30-50 while ten were students from the age group 20-30. Having done so, an attempt was made to explore the responses to CSH by females and to find if there was any difference in the way the working-women responded as compared to those by female students. For this, 2 structured questions were asked to each participant.

Participants were asked the following 2 main questions.

1. What is cyber sexual harassment according to you?

2. Have you faced cyber sexual harassment? If yes, what was your reaction? If no, how would you react if you ever face it?

The participants were also asked to explain the effects of CSH on the victims.

\section{Data Collection, Analysis, and Writing}

In qualitative studies, the major concerns are: adequacy of data, including sufficient time in the field, in addition to sufficient volume and variety of evidence used as data, to substantiate the explanations made in analysis (Morrow, 2005). The data were composed of over 7 hours of individual interviews collected over a 1month period. We transcribed the interview verbatim. At first, interviews were analyzed using McLeod's (2014) five-stage method. Stage one: immersion required reading and listening to interviews, to be sensitized to the respondents' covert meanings and overt meanings. The next stage: categorization comprised coding sections of the transcripts that highlighted meaning relevant to the study. Further the stage: phenomenological reduction consisted of reducing meaning units into important themes. Stage four: triangulation involved comparison of themes with one another and to raw data to isolate the more important themes from the less important ones. In stage five: interpretation, themes were compared with existing literature.

The investigation began with immersion, probing each detail of the data to develop a strong foundation in the data (Corbin and Strauss, 2014). Next, in open coding, raw data were broken down into convenient analytical fragments to enable the identification of basic concepts (Corbin and Strauss, 2014).Codes were developed on the basis of words used by the participants. Thereafter, axial coding was done and the data were 
put back together again by linking the codes to one another and forming categories. To understand the categories better, data and codes were systematically compared. Lastly, selective coding was carried out, in which a core category was selected and its relationship with the major categories was extrapolated. Core category related to all other categories, it occurred frequently in the data, it related to other categories, and it was generalizable to other phenomena. Thus it was done as per suggested by Corbin and Strauss (2014).

A visual model of the plan of action was developed to represent the participants' responses to CSH. As is typical of grounded-theory methods (Glaser and Strauss, 1967), the authors searched for disconfirming evidence within the data for the analytical framework and evolving model.

\section{Findings}

Participants' responses were mainly focused on CSH faced by them or known to them on social networking sites. The responses were studied for common word usage, similar ideas, and shared meanings to discern emerging themes.

When enquired what cyber sexual harassment is according to them, $75 \%$ of the respondents stated that posting of lewd comments, obscene photographs, images and videos without permission in order to cause mental abuse referred to cyber sexual harassment. Table 2 highlights a few indicative statements by the respondents:

Table-2. Responses.

\begin{tabular}{l|l|l}
\hline R3 & Corporate HR & $\begin{array}{l}\text { Another form of this can be imposing sexual images, referring private body } \\
\text { parts or sex organs, sending indecent images etc. }\end{array}$ \\
\hline R4 & Doctor & Offensive and bad posts and photographs. \\
\hline R8 & Corporate Trainer & $\begin{array}{l}\text { In my view, cyber sexual harassment is targeting an individual and exerting } \\
\text { abusive comments in the form of voice or video. }\end{array}$ \\
\hline R11 & Student & $\begin{array}{l}\text { As much as I know, there have been instances of men passing lewd comments } \\
\text { in a chat and of them sending vulgar messages, pictures and videos through } \\
\text { social media sites. }\end{array}$ \\
\hline R14 & Student & $\begin{array}{l}\text { Posting obscene-morphed pictures of people. People who perpetrate this act, } \\
\text { steal photographs of victims from social media websites, edit it and circulate it } \\
\text { online. }\end{array}$ \\
\hline R20 & Student & $\begin{array}{l}\text { Cyber Sexual Harassment, for me, means for example someone uploading } \\
\text { someone's nude pictures without permission. }\end{array}$ \\
\hline
\end{tabular}

The remaining $25 \%$ believed that cyber sexual harassment is every activity which is sexual in nature see Table 3.

Table-3. Responses.

\begin{tabular}{l|l|l}
\hline R10 & Freelancer & $\begin{array}{l}\text { According to me, if any gender makes any unwanted sexual advance } \\
\text { towards the opposite gender on net like chat rooms, Facebook or } \\
\text { WhatsApp, it is Cyber Sexual Harassment. }\end{array}$ \\
\hline R19 & Student & $\begin{array}{l}\text { According to me it's unwelcome use of information technology for } \\
\text { sexual violence and cyber stalking which is sexual in nature. }\end{array}$ \\
\hline
\end{tabular}

They were further asked if they have ever faced $\mathrm{CSH}$, what their reaction was or if not, how they would react. To this it was found majorly the following three actions are generally taken or thought about as a step see Table 4.

Table-4. Actions taken by respondents.

\begin{tabular}{l|l|l}
\hline 1. & Blocked the person & $38 \%$ \\
\hline 2 & Renortedabuse/RenortedtoCvber Cell Or Police & $52 \%$ \\
\hline 3. & Too legal action & $10 \%$ \\
\hline
\end{tabular}

\section{Discussion}

The study clearly indicates that most of the participants understood CSH as an act of posting comments, pictures and videos, lewd and offensive in nature; while a few others also stated that Cyber Sexual Harassments was any kind of sexual advance online. Experts in the field were consulted and their understanding of $\mathrm{CSH}$ was made note of.

When a practicing advocate was requested to opine on her views on what CSH is, she stated, "The recently enacted "The Sexual harassment of Women at Workplace (Prevention, Prohibition and Redressal) Act, 2013 defines "sexual harassment" (Section 2 (n) as it includes any one or more of the following 
unwelcome acts or behaviour (whether directly or by implication) namely:- i i) physical contact and advances; or (ii) a demand or request for sexual favours; or (iii) making sexually coloured remarks; or (iv) showing pornography; or (v) any other unwelcome physical, verbal or non-verbal conduct of sexual nature; Therefore, any such act when committed with the help of computer or technology could be cyber sexual harassment. Further, the Information Technology Act, 2000 (amended in 2008) also relates to cyber offences. Cybercrimes relating to women includes: harassment via emails, cyber-stalking, cyber pornography, defamation, morphing, email spoofing. We had Section 66A of this Act recently being struck down by the Hon'ble Supreme Court in Shreya Singhal's case."If somebody is booked under Section 66A, the person can face up to 3 years of imprisonment along with a fine.

But Section 66A has some problems.

Section $66 \mathrm{~A}$ is unclear and has some undefined terminology. The definition of

- What is 'insulting' or 'injurious' is not clearly defined.

- Is a rape threat a comment about physical appearance or maligning of public opinions?

- Is 'annoyance' the same as 'criminal intimidation' or 'enmity'?

- Under whose purview does the defining of these ambiguous terms fall?

Thus Internet advocates along with others who talk about freedom of expression as a human right find Section 66A directly contradiction these rights.

In such a case the following sections can be used.

Section 509: Word, gesture or act intended to insult the modesty of a woman.

Section 499: Defamation: Harming the reputation of a person through words, signs, or visible representations. Many women bloggers and Tweeters say that the violent sexist slander they receive goes on to create an irrecoverably negative message for them within their communities, societies, etc.

Section 503: Criminal Intimidation: One of the most widespread incitements to violence against women on the Internet is through the form of rape threats.

Section 507: Criminal intimidation by an anonymous communication: Rape threats - and other threats of violence - where the harasser is unknown (useful in a cyber world of 'trolls' and fluid identities) can be addressed under this section.

Section 228a: Disclosure of the identity of victims of certain offences: Disclosure of the identities of rape victims is prohibited by law. Images of rape victims as well as images and videos of rape are sometimes published on the Internet to silence victims and intimidate other women - this is not legal.

Another advocate described CSH as, "According to me any sexual advances through cyberspace are sexual advances through online chatting, recording online audio/video or chatting history of private conversation between the parties, and later on using the same for any kind of emotional torture, blackmail, etc. Even now a day's one, hacking of social media accounts and sending morphed pics, video and sexual contents are different kind of sexual harassment incidences. Many times when the any individual by using fake identity on social media, develops intimacy and thereafter start blackmailing or sending sexually coloured communications is also covered under cyber sexual harassment." He shared his experience related to CSH in the words, "One of my clients faced such a harassment from his own husband with whom he was having very strained relationship and were fighting criminal cases against each other. And the husband started sending the video clips and pics which they shares online or online video chatting between them during courtship, which was nothing but private moments between the engaged couple. We had very hard time to get the criminal case registered but in vain even the so called cyber cell of the Police was also of no help. Finally we could not register any FIR for cyber sexual harassment and under I.T. Act. In between however when we started pursuing the matter, few times police personal had called the husband to ask his version, which put him under pressure and finally the matter was mutually settled and the divorce was done. The young girl, decided not to pursue the matter. That was the only experience I have, which I encountered with the administration and the experience was very bad. If at all I face such an act, I will definitely take the issue to its conclusion, by moving to court by filing criminal complaint, and would not prefer FIR."

The District Child Protection Officer of a state shared, "When any words, pictures, movies or something disturb/harass mentally or psychologically through the content of any cyber media including WhatsApp, mail or any other digital media - considered as CSH. The help of Cyber Cell is taken in cases of CSH.”

The study also found that each participant, irrespective of whether she is a working woman or a student would respond to Cyber Sexual Harassment in a no-nonsensical manner.

Following major themes emerged from the participants' responses on what they do in cases of CSH:

\subsection{Identifying the Act of CSH}

Most of the participants (90\%) stated that it is necessary to understand the undesirable advances of an individual right in the beginning. The moment the initial "innocent" compliments on one's beauty turn into comments related to one's physical stats, one should beware and strictly communicate one's discomfort to the sender. This has also been identified in studies by Harriot 2010, Shaw 1990. 


\subsection{Blocking the Person}

Participants opined that if it is found that merely communicating discomfort is not working, the contact can very well be blocked to avoid further annoyance. Blocking the contact gives an opportunity to the sender to own up for one's mistake (if it is) and apologize. Moreover, it is also an attempt of a female to follow a procedure to escalate the matter in future, if need arises. Thesis a reiteration of what Simons, R.N. (2015) in his study said.

\subsection{Reporting Abuse \& Seeking Assistance from Cyber Cell/Police}

Reporting abuse is the next step to ensuring virtual safety from lecherous comments. It sends an indication that the sender has been annoying one and that an action is needed to keep the sender's actions in check. Seeking assistance from the Cyber Cell/Police facilitates in bringing the culprit to task. Ways of responding to such incidents also appear in a website by Robinson and Segal (2016) The study found that whether the female is working or studying, she agreed to involve the Cyber Cell/Police in handling matters related to $\mathrm{CSH}$ without any intimidation. A respondent - a student, said, "I have personally never faced cyber sexual harassment but I came pretty close to it once. My immediate reaction was to block all my data in social networking sites from the outside world. I researched on the dark side of internet and how the world of cybercrime works. I will be very upfront about it. With so much data in cloud and so many means of distorting data prevalent in modern times, I would certainly try to stop the crime from happening to other victims." Her statement clearly indicates the courage with which she would face the situation by not only taking the right measures to combat it but also to make others aware by exposing such acts of lewdness.

\subsection{Taking Legal Action}

There were varied views related to the existing laws in India to take care of CSH. Only two participants (participant 6 \& 8), both professionals, indicated the importance of legal action in dealing with cases of CSH. However, according to participant 10, a professional woman in the age group of 30-50, who had faced an act of $\mathrm{CSH}$, "Cyber law is not as strict as we read and it has lots of loose ends."

The study also highlights the effects of CSH on victims. Probing into the issue of CSH and reviewing the literature, it was found that though there is some awareness level but often the intensity and seriousness is undermined (Sheryl, Michelle, Aneta and Jessica, 2014)

Following are the two crucial effects as identified by the victims:

\section{Mental Torture}

When there was a probe into the effects of $\mathrm{CSH}$, the experiences narrated were quite painful to make note of. How much mental torture can a person undergo is quite evident from what was shared by participant 1, a dentist by profession, now working with a multinational. She stated, "Yes. I had no time to react but undergo third degree torture by my extended family for all possible worst case scenarios they could imagine. I had to undergo dope test, gynaecological examinations, and Psychiatry trials to be certified as "GOOD". Anyway my body has been tough enough to take all this non sense and mentally dint break down and give up. Anyway I would say this has helped me develop a NEVER GIVE UP ATTITUDE. People who knew every bit of what I went through today think maybe they were wrong. On a lighter note I now have a FB account. But this time any harassment by any one in any form my family has promised me that they will definitely ensure that the necessary price is borne by whoever does so."

A review of various studies strengthened that cyber sexual harassment is always not sexual in nature. It creates other kind of mental and psychological trauma as well (Blumenfeld and Cooper, 2010; Finn, 2004; Hinduja and Patchin, 2008; Lindsay and Krysik, 2012).

\section{Damage to Relationship and Trust}

CSH surely contributes in damaging relationship and trust. It has been reconfirmed in the literature Idris et al (2012). In the current survey one of the participants said, "Another incident that I would like to quote here is of a friend, a couple of years older. She had just got engaged when her ex-boyfriend hacked her FB account (he had the password), put up a profile pic of the girl and the guy sitting together intimately, messaged all her friends and relatives from her account that she was getting married forcefully. We reported her profile as spam and the account was blocked by FB. The girl's family filed a complaint, and the guy was tracked and put behind bars. The girl's engagement, however, fell off." It was not the falling off of the engagement that tormented her and her family but the irreparable damage caused to their trust in relationships. 


\section{Conclusion \& Recommendations}

Based on the study, the researchers propose the following action plan as an initial strategy to combat CSH before taking a formal legal action see Figure 1:

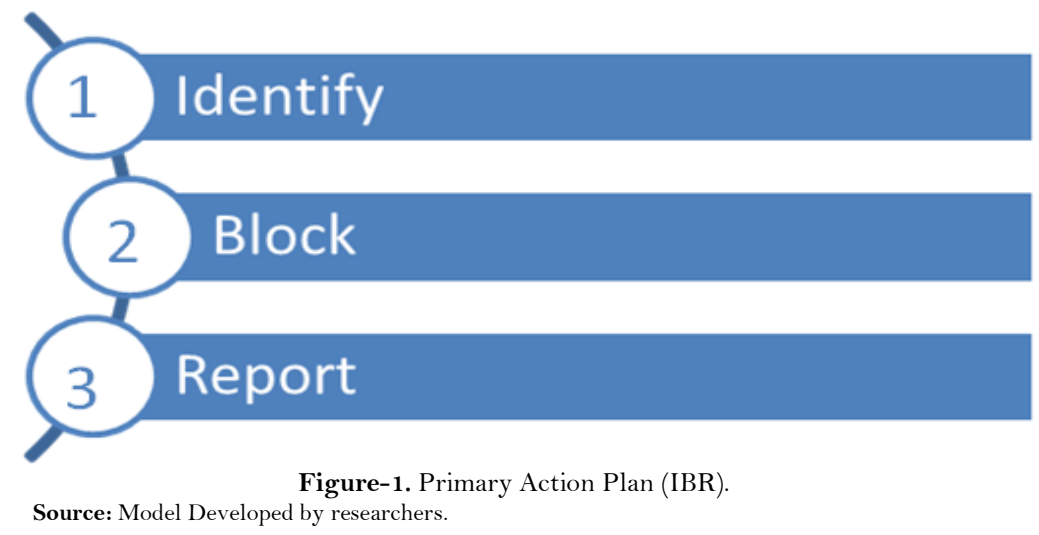

\section{Identify}

It is imperative to identify acts of CSH in the nascent stage. Women, in particular, girls, often ignore or delete the unwanted posts, photographs, and videos. This generally encourages the abuser and makes them bold enough to post more of these and with even more intensity. It is advisable not to react or respond to any such material.

\section{Block}

One needs to remember that most of the social networking sites are equipped with the 'block' action, by way of which the abuser can be blocked from one's account. "Blocking is a strategy that deals with the abuse on an individual basis, rather than bringing out its structural foundations" (Kovacs, Padte and Shobha 2013).

\section{Report}

There are mechanisms to report abuse on the social networking sites. To be specific, Facebook has a mechanism in place that permits users to report abuse, whether it is for harassment on chat or if abusive comments are being posted on the wall or if any content is considered inapt.

It is further suggested that in case the victim is skeptical about reporting the abuse to legal authority as police due to various reasons like fear, perception that no action is taken or any other negative perception, saving face in society etc. the other option is to file a Public Interest Litigation (PIL).

PIL is a way of using the law strategically to effect social change. The benefits of PIL can be listed as:

\section{Provide Access To Justice:}

Many people are simply not in a position to take legal action themselves. This may be due to personal, financial or time issues, or they may not be aware of their rights or who to take their complaint to, or they may not have the capacity to advocate for themselves. Such individuals can get access to justice by filing a PIL.

\section{Hold Government To Account:}

PIL can be used to challenge government policies and procedures that violate human rights or equality standards and to provoke the political system into responding to a problem it has hitherto ignored. In doing so, it can help provide a check on government, statutory and public bodies, holding them to account for failures to uphold domestic and international human rights and equality standards to which they are bound.

\section{Raise Awareness:}

As well as providing legal redress, PIL is a useful way of raising awareness of issues. A high profile case can prompt public debate and bring about pressure for social and legislative change outside the court room.

\section{Save Costs:}

Costs are a major factor for most people considering litigation. By taking strategic cases, PIL can create a positive impact for a wide group of people without each of them having to go before the courts themselves, thus saving time and money for both victims and the courts

Though filing PIL can also be matters of public importance but as mentioned in literature The matters of private nature: may include:

- Threat to or harassment of the petitioner by private persons,

- Seeking enquiry by an agency other than local police, 
- Seeking police protection,

- Early hearing of matters pending in High Court and subordinate courts and are not considered matters of public interest.

Although it is convenient for women to ignore the abuse and the abuser, and further to shy away from the social networking sites to be safe from CSH, it is far from being advisable. One needs to understand one's rights and act accordingly. Some non-legal actions have also been identified in a study by Phadke, 2010.

\section{Limitations and Implications}

Justlike the other qualitative studies, the conceptual action planresulting from this study is not proposed to generalize to large populations of persons. In fact, the conceptual action plan is a unique combination of the participants, investigators, and the research context. Readers need to examine critically the evolving conceptual action plan proposed here in the context of their distinctive settings to decide if it transfers to their specific circumstances. The most obvious limitation of this study is the narrow geographic diversity of the participants. Accordingly, future research should include diverse expressions and which might address specific $\mathrm{CSH}$ perspectives to gain deeper insights into the topic. The researchers feel that variety of respondents based on culture will enhance the understanding of the issue. The study could provide holistic global insights if the respondents are from diverse backgrounds and different countries. The study records the responses of only female participants. The responses from males and the other gender may further add inputs to the current research.

Despite the limitations of the present study, many implications exist for future research, practice, and training. Most of the past scholarly work related to CSH has been conceptual rather than empirical. Future studies may contribute to a growing knowledge base by providing women with empirically based guidelines for combating CSH. Moreover, a strong qualitative groundworkaims at providing a foundation for mixed methods research and quantitative-outcome research. This study addressed a question that had yet to be examined in the current literature on CSH: How do victims of CSH integrate the action plan proposed in the study. The conclusion and recommendations have valuable implications for research and training.

\section{References}

Agarwal, R. (2013). Cyber crime against women and regulations in India. Available from: http://www.tmu.ac.in/gallery/viewpointsdcip2013/pdf/track4/t-403.pdf.

Barak, A. (2005). Sexual harassment on the internet. Social Science Computer Review, 23(1): 77-92.

Bastiaensens, S., Vandebosch, H., Poels, K., Van Cleemput, K., DeSmet, A. \& DeBourdeaudhuij, I. (2014). Cyberbullying on social network sites. An experimental study into bystanders' behavioural intentions to help the victim or reinforce the bully. Computers in Human Behavior, 31: 259-271.

Baumgartner, S. E., Valkenburg, P.M. \& Peter, J. (2010). Unwanted online sexual solicitation and risky sexual online behaviour across the lifespan. Journal of Applied Developmental Psychology, 31: 439-447.

Beckman, L., Hagquist, C. \& Hellström, L. (2013). Discrepant gender patterns for cyberbullying and traditional bullying: An analysis of Swedish adolescent data. Computers in Human Behavior, 29(5): 1896-1903.

Blumenfeld, W. J. \& Cooper, R. M. (2010). LGBT and allied youth responses to cyberbullying: Policy implications. International Journal of Critical Pedagogy, 3: 114-133.

Burke, S.C., Wallen, M., Vail-Smith, K. \& Knox, D. (2011). Using technology to control intimate partners: An exploratory study of college undergraduates. Computers in Human Behavior, 27: 1162-1 167.

Calvete, E., Orue, I., Estévez, A., Villardón, L. \& Padilla, P. (2010). Cyberbullying in adolescents: Modalities and aggressors' profile. Computers in Human Behavior, 26(5): 1128-1135.

Chen, Y., Zhou, Y., Zhu, S. \& Xu, H. (2012). Detecting offensive language in social media to protect adolescent online safety. In Privacy, Security, Risk and Trust (PASSAT), International Conference on Social Computing (SocialCom). pp: 71-80.

Citron, D. K. (2014). Hate crimes in cyberspace. Cambridge, Massachusetts: Harvard University Press.

Corbin, J. \& Strauss, A. (2014). Basics of qualitative research: Techniques and procedures for developing grounded theory. 4th Edn., Thousand Oaks, CA: Sage.

Cross, K. A. (2014). Ethics for cyborgs: On real harassment in an "unreal” place. Loading..., 8(13). Available from: http://journals.sfu.ca/loading/index.php/loading/article/view/140.

Dadvar, M. \& de Jong, F. (2012). Cyberbullying detection: A step toward a safer internet yard. In Proceedings of the 21 st International Conference Companion on World Wide Web. pp: 121-126.

Dadvar, M., Jong de F., Ordelman, R. \& Trieschnigg, D. (2012). Improved cyberbullying detection using gender information. In Proceedings of the Twelfth Dutch-Belgian Information Retrieval Workshop, pp. 23-25.

Dinakar, K., Reichart, R. \& Lieberman, H. (2011). Modeling the detection of textual cyberbullying. In The Social Mobile Web. Available from: http://www.aaai.org/ocs/index.php/ICWSM/ICWSM11/paper/download/3841/4384 
Dinakar, K., Jones, B., Havasi, C., Lieberman, H. \& Picard, R. (2012). Common sense reasoning for detection, prevention, and mitigation of cyberbullying. ACM Transactions on Interactive Intelligent Systems, 2(3): 18:1-18:30.

Doll, J. \& Giumetti, G.W. (2015). Cyber-sexual harassment: Effects on affect, engagement, and performance. Academy of Management Journal, 20(1): 79-98.

Dreßing, H., Bailer, J., Anders, A., Wagner, H. \& Gallas, C. (2014). Cyberstalking in a large sample of social network users: Prevalence, characteristics, and impact upon victims. Cyberpsychology, Behavior, and Social Networking, 17: 61-67. Available at:10.1089/cyber.2012.0231.

Drouin, M. \& Tobin, E. (2014). Unwanted but consensual sexting among young adults. Computers in Human Behavior, 31: 412-418.

Drouin, M., Ross, J. \& Tobin, E. (2015). Sexting: A new digital vehicle for intimate partner aggression? Computers in Human Behavior, 50: 197-204.

Fenaughty, J. \& Harré, N. (2013). Factors associated with distressing electronic harassment and cyberbullying. Computers in Human Behavior, 29(3): 803-811.

Finn, J. (2004). A survey of online harassment at a university campus. Journal of Interpersonal Violence, $19(4): 468-83$

Gamez-Gaudix, M. Almendrios, C. \& Borrajo, E.C. (2015). Prevalence and association of sexting and online sexual victimization among Spanish adults. Sexuality Research and Social Policy, 12(2): 145-154.

Glaser, B. G. \& Strauss, A. L. (1967). The discovery of grounded theory: Strategies for qualitative research. Chicago, IL: Aldine.

Halder, D. \& Karuppannan, J. (2009). Cyber socializing and victimization of women, 5-26. Available from: http://www.doiserbia.nb.rs/img/doi/1450-6637/2009/1450-66370903005H.pdf.

Halder, D \& K. J. (2010). Cyber victimization in India. A Baseline Survey Report. Tamil Nadu: Centre for Cyber Victim Counselling, 1-22. Accessed on: 17 July 2014. Available from: http://www.cybervictims.org/CCVCresearchreport2010.pdf.

Harriot v. National Money Mart Co, (2010). supra, note 12. Available from: http://www.ohrc.on.ca/so/node/10279.

Henry, N. \& Powell, A., (2016). Technology-facilitated sexual violence: A literature review of empirical research. Trauma Violence Abuse, 19(2): 195-208. Available at: 10.1177/1524838016650189.

Hinduja, S. \& Patchin, J. W. (2008). Cyberbullying: An exploratory analysis of factors related to offending and victimization. Deviant Behavior, 29(2): 129-156.

Idris, M. A., Dollard, M. F., Coward, J. \& Dormann, C. (2012). Psychosocial safety climate: Conceptual distinctiveness and effect on job demands and worker psychological health. Safety Science, 50(1): 1928. Available at: http://dx.doi.org/10.1016/j.ssci.2011.06.005.

Kovacs, A., Padte, R.K. \& Shobha, S.V. (2013). An exploratory study of women and verbal online abuse in India. Internet Democracy Project, New Delhi, India.

Lapidot-Lefler, N. \& Barak, A. (2012). Effects of anonymity, invisibility, and lack of eye-contact on toxic online disinhibition. Computers in Human Behavior, 28(2): 434-443.

Lindsay M. \& Krysik, J. (2012). Online harassment among college students: A replication incorporating new Internet trends. Information Communication and Society, 15(5): 703-719.

Lindsay, M., Booth, J. M., Messing, J. T. \& Thaller, J. (2015). Experiences of online harassment among emerging adult's emotional reactions and the mediating role of fear. Journal of Interpersonal Violence, 31(19): 3174-3195.

Majumdar, S. (2003). Sexual control and violence. The Tribune (Chandigarh) 10-Aug-2003.

McLeod, J. (2014). Doing research in counseling and psychotherapy. 3rd Edn., London, UK: Sage.

Meyer, R. \& Cukier, M. (2006). Assessing the attack threat due to IRC channels. In Proceedings of the International Conference on Dependable Systems and Networks. pp: 467-472.

Moor, P.J., Heuvelman, A. \& Verleur, R. (2010). Flaming on YouTube. Computers in Human Behavior, 26(6): 297-315.

Morrow, S. L. (2005). Quality and trustworthiness in qualitative research in counseling psychology. Journal of Counseling Psychology, 52: 250-260. Available at: http://dx.doi.org/10.1037/0022-0167.52.2.250.

Morrow, S. L. (2007). Qualitative research in counseling psychology: Conceptual foundations. The Counseling Psychologist, 35: 209-235. http://dx .doi.org/10.1177/0011000006286990

Myiah, J. H., Vincent, J. C. \& Jay, D. H. (2014). How could you think that?: Understanding intentions to engage in political flaming. Cyberpsychology, Behavior, and Social Networking, 17(8): 1201-1219.

Nussbaum, M. C. (2010). Objectification and internet misogyny. In S. Levmore \& M.C. Nussbaum (Eds.), The offensive internet: Speech, privacy, and reputation, Cambridge, M.A.: Haward University Press. pp: 68-87.

Phadke, S. (2010). Non-legal strategies women use to deal with online abuse. Internet Democracy Project Report, New Delhi, India. pp: 1-5. 
Ptaszynski, M., Dybala, P., Matsuba, T., Masui, F., Rzepka, R., Araki, K. \& Momouchi, Y. (2010). In the service of online order: Tackling cyber-bullying with machine learning and affect analysis. International Journal of Computational Linguistics Research, 1(3): 135-154.

Reynolds, K., Kontostathis, A. \& Edwards, L. (2011). Using machine learning to detect cyberbullying. In Machine Learning and Applications and Workshops (ICMLA), 2011 10th International Conference on, 2: 241-244.

Robinson, L. \& Segal, J. (2016). Dealing with cyberbullying. Available from: http://www.helpguide.org/articles/abuse/cyberbullying.htm.

Rowe, I. (2014). Civility 2.0: A comparative analysis of incivility in online political discussion. Information, Communication \& Society, $\mathrm{O}(0): 1-18$.

Sandelowski, M. (1995). Sample size in qualitative research. Research in Nursing \& Health, 18: 179- 183. Available at: http://dx.doi.org/10.1002/nur.4770180211.

Santana, A. D. (2014). Virtuous or vitriolic. Journalism Practice, 8(1): 18-33.

Shaw v. Levac Supply Ltd, (1990). Supra, note 17; Fornwald v. Astrographic Industries Ltd. (1996), supra, note 24 at D/322. Farris v. Staubach Ontario Inc., 2011, supra, note 23. Available from: http://www.ohrc.on.ca/en/book/export/html/10245.

Sheryl, A. H., Michelle, T., Aneta, K. \& Jessica, A.H. (2014). Predictors of traditional and cyber-bullying victimization a longitudinal study of Australian secondary school students. Journal of Interpersonal Violence, 30(15): 2567-2590.

Simons, R.N. (2015). Addressing gender-based harassment in social media: A Call to Action Proceedings of the iConference. Available from: http://hdl.handle.net/2142/73743.

Staude-Mu“ller, F., Hansen, B. \& Voss, M. (2012). How stressful is online victimisation? Effects of victim's personality and properties of the incident. European Journal of Developmental Psychology, 9(5): 517519.

Sheryl, A.H., Michelle, T., Aneta K. \& Jessica, A. H. (2014). Predictors of traditional and cyber-bullying victimization a longitudinal study of Australian secondary school students. Journal of Interpersonal Violence, 30(15): 2567-2590.

Thompson, M. P. \& Morrison, D. J. (2013). Prospective predictors of technology-based sexual coercion by college males. Psychology of Violence, 3(3): 233-246.

Walia, P. (2013). Facebook abuse tops cyber-crime chart in Punjab. Hindustan Times, June 30.

Yang, M., Melody, K., Hsinchun, C. and Yijun, L. (2012). Artificial immune system for illicit content identification in social media. Journal of the American Society for Information Science and Technology, 63(2): 265-269.

Ballard, M. E. \& Welch, K. M. (2015). Virtual warfare cyberbullying and cyber-victimization in MMOG Play. Games and Culture.

Haruna, I., Adaja, J., Samson, A. \& Aye, G.A. (2016). Analysis of the causes and effects of sexual harassment on the performance of female employees in some selected organizations in Kogi State, Nigeria. International Journal of Democratic and Development Studies (IJDDS), 2(2): 31-39. 